\title{
A study on the prevalence of thinness and obesity in school going adolescent girls of Kashmir Valley
}

\section{Darakshan Ali ${ }^{1}$, Rohul Jabeen Shah ${ }^{1}$, Anjum Bashir Fazili ${ }^{1}$, MM Rafiq $^{2}$, Beenish Mushtaq ${ }^{2}$, Qazi Mohammad Iqbal ${ }^{1}$, Sameena Yousuf Dar ${ }^{1}$}

\author{
${ }^{1}$ Department of Community Medicine, Sher-i-Kashmir Institute of Medical Sciences, Soura, Srinagar, Jammu and \\ Kashmir, India. \\ ${ }^{2}$ Department of Community Medicine, Sher-i-Kashmir Institute of Medical Sciences Medical College, Bemina, Jammu \\ and Kashmir, India
}

Received: 20 May 2016

Accepted: 10 June 2016

\author{
*Correspondence: \\ Dr. Darakshan Ali, \\ E-mail: drdarakshan11@yahoo.com.
}

Copyright: (c) the author(s), publisher and licensee Medip Academy. This is an open-access article distributed under the terms of the Creative Commons Attribution Non-Commercial License, which permits unrestricted non-commercial use, distribution, and reproduction in any medium, provided the original work is properly cited.

\begin{abstract}
Background: A vast majority of girls in India are suffering from either general or specific morbidities. Under nutrition and obesity are important nutritional problems in adolescents. In Indian adolescents the prevalence of under nutrition is $53.1 \%$ in males and $39.5 \%$ in females. In India the prevalence of obesity is also increasing with $8.3 \%$ in adolescent boys and $5.5 \%$ in adolescent girls. This is especially seen in the urban affluent class because of unhealthy eating, consumption of junk and fast foods and also due to changing lifestyles and physical inactivity. Adolescent girls constitute a socially disadvantageous group in our society.

Methods: A cross sectional study design was adopted and the study was conducted in randomly selected schools in three districts of Kashmir Valley during April 2014 to March 2015. A total of 428 girls in the age group of 12 to 18 years were included in the study. Data was collected using a pre-tested and pre-structured proforma which included assessment of the dietary habits, anthropometric measurements and general physical examination of the study participants.

Results: The prevalence of thinness in the study population was $35.70 \%$ and was significantly associated with SES, mother's literacy and mother's occupation ( $\mathrm{p}$ value $<0.001,0.039$ and $<0.001$ respectively).The prevalence of overweight was $7.20 \%$.It was observed that age, SES and residence had a significant association with the prevalence of overweight ( $\mathrm{p}$ value $0.010,<0.001$ and 0.001 respectively). The prevalence of overweight by WHR was $4.40 \%$ and that of obesity was $3.30 \%$.

Conclusions: Thus it is concluded from this study that a considerable proportion of adolescent girls suffered from thinness and obesity. We recommend that requisite measures be taken to address these concerns as this group constitutes a sizeable proportion of the Indian mothers of our future generation and their well-being is critically important for improving the nutritional health of women of the nation.
\end{abstract}

Key words: Adolescent, Thinness, Overweight, Obesity

\section{INTRODUCTION}

WHO defines adolescence as the segment of life between the ages of 10 to 19 years. This transitional stage of life is characterized by rapid physical, social and psychological development, sexual maturity and onset of sexual activity, desire for experimentation and transition from dependence to relative independence. ${ }^{1}$ Good adolescent health and nutritional status has an inter-generational effect. Therefore, adolescence is one of the important 
stages of the life cycle in terms of health interventions. It is one window of opportunity which can be used effectively to inculcate good practices in individuals and hence in community. ${ }^{2}$

In India adolescents constitute about $22.8 \%$ of total population which in absolute numbers is approximately 273 million forming a significant proportion of the population. ${ }^{3}$ The importance of adolescents lies in the fact that they are going to be the adults of tomorrow and the future development of a nation rests in large part on the prospect of having adults who are educated, healthy and economically productive. ${ }^{4}$

Adolescence is a timely period for the adoption and consolidation of sound and healthy dietary habits. Their lifestyle and eating habits along with underlying psychosocial factors are particularly important threats to adequate nutrition. Moreover the period of adolescence seems to be the last chance to correct the growth lag and malnutrition. This is of importance especially in adolescent girls where malnutrition could have adverse intergenerational effects thereby affecting not only the adolescent girl but the future generations as well. The health of an adolescent girl impacts pregnancy while the health of a pregnant woman impacts the health of the newborn and the child. The mother's condition before pregnancy is a key determinant of its outcome. In North India the prevalence of thinness was found to be $43.8 \%$ in boys and $30.1 \%$ in girls taking cut off value of BMI as less than $5^{\text {th }}$ percentile. ${ }^{5}$ It has also been reported that half of adolescents (boys and girls) have below normal body mass index (BMI). ${ }^{3}$ Obesity is also increasing especially in the urban affluent class because of unhealthy eating, consumption of junk and fast foods and also due to changing lifestyles and physical inactivity. The number of adolescents who are overweight or obese is increasing in both low- and high-income countries. The prevalence of obesity in adolescents boys is $8.3 \%$ and in adolescent girls is $5.5 \%{ }^{6}$

Since in this part of the country very little work in this regard has been done so far, our study is an attempt to identify the various nutritional problems of adolescent girls. This would help the planners and health policy makers to plan strategies in order to address these problems in a friendly manner and to improve the overall health of adolescent girls - our future mothers.

Objectives of the study was to assess the prevalence of thinness and obesity in school going adolescent girls of Kashmir valley and identify the various factors associated with thinness and obesity in the above defined population.

\section{METHODS}

A cross sectional study design and multistage random sampling technique was adopted and the study was conducted in randomly selected Girls high schools and
Girls higher secondary schools in three districts of Kashmir Valley during April 2014 to March 2015. Girls in the age group of 12 to 18 years studying in these schools were included in the study.

The calculation of required sample size was carried out using prevalence (p) as $50 \%$ and an allowable error of $5 \%$ and using the formula:

$$
\begin{aligned}
& \mathrm{n}=\mathrm{Z}^{2} \mathrm{p}(1-\mathrm{p}) / \mathrm{e} 2 \\
& \mathrm{n}=\text { estimated sample size } \\
& \mathrm{p}=\text { expected prevalence } \\
& \mathrm{Z}=\text { statistic for } 95 \% \text { level of confidence }(1.96) \\
& \mathrm{e}=\text { allowable error }
\end{aligned}
$$

Thus the sample size was 422 including a $10 \%$ for non responders. To round off, a sample size of 450 was taken (including a margin of $10 \%$ for non response rate).

One district was selected from each of the three geographical regions of Kashmir valley. District Srinagar was purposely selected from the central region because of its urban character and represented our urban adolescent population while as districts Baramulla and Pulwama were randomly selected from North Kashmir and South Kashmir respectively. These two districts represented our rural adolescent population.

Since the enrolment ratio of school going adolescent girls in the age group of 12-18 years in urban and rural areas of Kashmir Valley is 1.07:1, the calculated sample size was divided in the ratio of 1.07:1 between the selected urban and rural districts of Kashmir. ${ }^{7}$

The study was conducted in a total of 18 girls schools (9 high schools and 9 higher sec schools) out of which 12 were government schools and 6 were private schools (giving due weightage to the distribution of government and private schools in Kashmir Valley). ${ }^{8}$ The number of students to be taken from each school and class was calculated on the basis of Probability Proportional to Size (PPS) technique.

\section{Inclusion criteria}

Adolescent girls aged 12-18 years who gave consent/whose parents gave consent to be a part of this study was included in the study.

\section{Exclusion criteria}

1) Girls not consenting/ whose parents did not give consent to be a part of the study.

2) Girls not cooperating for anthropometry.

\section{Ethical issues}

Ethical clearance was sought from the Institutional Ethics Committee. Besides this, proper permission was taken from Director School Education, Kashmir and concerned 
Chief Educational Officers of all the three districts as well as from the school authorities. Informed consent was taken from parents of the students. Consent was taken from the student as well. Confidentiality was maintained at all times and girls in need of medical attention were appropriately referred.

\section{Tools for data collection}

Data was collected using a pre tested and pre structured proforma which included questions on social and demographic particulars and questions on diet and physical activity and a thorough clinical examination and anthropometry was also done.

The study population was categorized as thin, overweight and obese on the basis of BMI for age as per WHO growth reference values and they were also categorized on the basis of Waist-hip ratio as overweight and obese..$^{9,10}$

\section{Data analysis}

Data was analysed using SPSS version 20.00. The standard statistical tests like chi square (X2) and Fischer exact tests were applied. Multivariate analysis (Binary Logistic Regression) has also been used. A p value of $\leq$ 0.05 has been considered significant.

\section{RESULTS}

The total sample size calculated was 450 . However a non-response rate of $4.88 \%$ (22) was encountered. Thus a total of 428 adolescent girls, 12-18 years of age participated in the study.

The present study revealed the following findings:

Table 1 depicts the socio-demographic profile of the study population. It was observed that 207 (48.40\%) of the adolescents belonged to a rural area while as 221 $(51.60 \%)$ belonged to urban background. $242(56.50 \%)$ of the adolescents studied in government schools and 186 $(43.50 \%)$ studied in private schools. $162(37.90 \%)$ study population was in the age group of 12-14 years and $(62.10 \%)$ were in the age group of $15-18$ years. All of the participants were unmarried.

It was observed that almost all i.e. 410 (95.80\%) participants were Muslims, 17 (4\%) were Sikhs and only $1(0.20 \%)$ was Hindu. $300(70.10 \%)$ participants came from nuclear families and $128(29.90 \%)$ came from joint families.

Regarding mother's literacy and occupation it was seen that $207(48.4 \%)$ participants had illiterate mothers and $221(51.60 \%)$ had literate mothers and 339 (79.2\%) had mothers who were homemakers and 89 (20.80\%) had working mothers.
Table 1: Sociodemographic profile of the study population.

\begin{tabular}{|llll|}
\hline Socio-demographic & Variable & n & $\%$ \\
\hline Residence & Rural & 207 & 48.40 \\
\cline { 2 - 4 } & Urban & 221 & 51.60 \\
\hline Type of school & Government & 242 & 56.50 \\
\cline { 2 - 4 } & Private & 186 & 43.50 \\
\hline \multirow{2}{*}{ Age } & $12-14$ years & 162 & 37.90 \\
\hline Marital status & 15-18 years & 266 & 62.10 \\
\hline \multirow{2}{*}{ Religion } & Unmarried & 428 & 100 \\
\cline { 2 - 4 } & Married & 0 & 0.00 \\
\hline \multirow{2}{*}{ Type of family } & Muslim & 410 & 95.80 \\
\cline { 2 - 4 } & Hindu & 1 & 0.20 \\
\cline { 2 - 4 } & Sikh & 17 & 4.00 \\
\hline Mother's Literacy & Nuclear & 300 & 70.10 \\
\cline { 2 - 4 } status & Joint & 128 & 29.90 \\
\hline Mother's occupation & Illiterate & 207 & 48.40 \\
\cline { 2 - 4 } & Literate & 221 & 51.60 \\
\hline & Homemaker & 339 & 79.20 \\
\hline & Working & 89 & 20.80 \\
\hline
\end{tabular}

Table 2 depicts the distribution of study population on the basis of their SES. ${ }^{11} \mathrm{SE}$ classes I and II have been grouped together and considered as upper class, SE class III considered as middle class and SE classes IV and V together considered as lower SE class. It was observed that $45.56 \%$ (195) of the study population belonged to lower SE class followed by $37.62 \%$ (161) belonged to middle class and $16.82 \%$ (72) belonged to upper SE class.

Table 2: Socioeconomic status of the study population (modified B G Prasad's classification).

\begin{tabular}{|c|c|c|c|c|}
\hline $\begin{array}{l}\text { Socioeconomic } \\
\text { class }\end{array}$ & n & $\%$ & $\mathbf{n}$ & $\%$ \\
\hline I & 22 & 5.14 & \multirow[t]{2}{*}{72} & \multirow[t]{2}{*}{16.82} \\
\hline II & 50 & 11.68 & & \\
\hline III & 161 & 37.62 & 161 & 37.62 \\
\hline IV & 170 & 39.72 & \multirow[t]{2}{*}{195} & \multirow[t]{2}{*}{45.56} \\
\hline V & 25 & 5.84 & & \\
\hline Total & 428 & 100.00 & 428 & 100.00 \\
\hline
\end{tabular}

Table 3 depicts the age wise distribution of the study population by their mean weight and BMI for age. ${ }^{9}$ The mean weight of the study population was $45.70+9.69 \mathrm{~kg}$. The mean BMI for age of the study population was $18.69+3.32 \mathrm{~kg} / \mathrm{m}^{2}$. The prevalence of thinness in the study population was $35.70 \%$ (153) with highest prevalence seen at 16 years of age $(44.10 \%)$ and lowest prevalence at 17 years of age $(28.90 \%)$. The prevalence of overweight was $7.20 \%$ (31). Highest prevalence of overweight was observed at 12 years of age and lowest at 18 years of age $(1.70 \%)$. None of the study participants was obese. 
Table 3: Age wise distribution of the study population by their mean weight and BMI for age.

\begin{tabular}{|c|c|c|c|c|c|c|c|c|c|c|}
\hline \multirow[t]{2}{*}{ Age } & \multicolumn{2}{|c|}{$\begin{array}{l}\text { No. } \\
\text { adolescents }\end{array}$} & \multirow{2}{*}{$\begin{array}{l}\text { Weight } \\
\text { (kg) } \\
\text { Mean } \pm \text { SD }\end{array}$} & \multirow{2}{*}{$\begin{array}{l}\text { BMI for age } \\
\left(\mathrm{kg} / \mathrm{m}^{2}\right) \\
\text { Mean } \pm \text { SD }\end{array}$} & \multicolumn{2}{|c|}{$\begin{array}{l}\text { Normal (BMI } \\
-2 \text { SD to +1SD) }\end{array}$} & \multicolumn{2}{|c|}{$\begin{array}{l}\text { Thin } \\
\text { (BMI <-2SD) }\end{array}$} & \multicolumn{2}{|c|}{$\begin{array}{l}\text { Overweight (BMI } \\
>\text { 1SD) }\end{array}$} \\
\hline & $\mathrm{N}$ & $\%$ & & & $\mathrm{n}$ & $\%$ & $\mathrm{n}$ & $\%$ & $\mathrm{n}$ & $\%$ \\
\hline 12 & 63 & 14.71 & $38.34 \pm 7.62$ & $17.36 \pm 3.23$ & 33 & 52.40 & 21 & 33.30 & 9 & 14.30 \\
\hline 13 & 51 & 11.91 & $39.78 \pm 7.75$ & $16.98 \pm 3.13$ & 23 & 45.10 & 21 & 41.20 & 7 & 13.70 \\
\hline 14 & 48 & 11.21 & $44.06 \pm 7.68$ & $18.28 \pm 3.10$ & 28 & 58.30 & 18 & 37.50 & 2 & 4.20 \\
\hline 15 & 42 & 9.81 & $48.76 \pm 10.96$ & $19.61 \pm 3.57$ & 23 & 54.80 & 14 & 33.30 & 5 & 11.90 \\
\hline 16 & 68 & 15.88 & $46.76 \pm 8.85$ & $18.56 \pm 3.12$ & 35 & 51.50 & 30 & 44.10 & 3 & 4.40 \\
\hline 17 & 97 & 22.66 & $49.64 \pm 8.40$ & $19.74 \pm 3.03$ & 65 & 67.00 & 28 & 28.90 & 4 & 4.10 \\
\hline 18 & 59 & 13.78 & $50.11 \pm 9.56$ & $19.66 \pm 3.22$ & 37 & 62.70 & 21 & 35.60 & 1 & 1.70 \\
\hline Total & 428 & 100.00 & $45.70 \pm 9.69$ & $18.69 \pm 3.32$ & 244 & 57.00 & 153 & 35.70 & 31 & 7.20 \\
\hline
\end{tabular}

Table 4 shows the relation between BMI of the study population with their sociodemographic profile. It was seen that age, SES and residence of the participant had significant association with BMI ( $\mathrm{p}$ value $0.035,<0.001$ and 0.016 respectively) while type of family, mothers literacy, mothers occupation and the type of school were not significantly associated with BMI of the participant ( $p$ value $0.325,0.119,0.202$ and 0.659 respectively).

Further it was observed that the prevalence of thinness was significantly associated with SES, mothers literacy and mothers occupation ( $\mathrm{p}$ value <0.001, 0.039 and $<0.001$ respectively). It was observed that prevalence of thinness was higher in lower SE class $(53.84 \%)$ followed by middle class $(22.36 \%)$ and upper class $(16.66 \%)$. It was observed that the prevalence of thinness was higher in participants with illiterate mothers $(40.60 \%)$ and whose mothers were homemakers by occupation $(37.76 \%, \mathrm{p}$ value $<0.001)$. The association of prevalence of thinness with age, residence, type of family and type of school was not statistically significant.

With regard to the prevalence of overweight it was observed that age, SES and residence had a significant association with the prevalence of overweight ( $\mathrm{p}$ value $0.010,<0.001$ and 0.001$)$. Prevalence of overweight was more in 12-14 years age group (11.10\%), adolescents belonging to upper class $(31.90 \%)$ and adolescents from urban background $(10.00 \%)$.

On binary logistic regression analysis (multivariate analysis) it was seen that a strong statistical association existed between the prevalence of thinness and SES $(\mathrm{p}<0.001)$ with a higher prevalence seen in lower SE class than upper class.

The risk of thinness was 3.69 times higher in lower class than in upper class. The association of the prevalence of thinness with age, residence, type of family, mother's literacy, mother's occupation and type of school was however not found to be significant (Table 5).

Table 7 shows the age wise distribution of the study population by their mean WHR. ${ }^{10}$ The mean WHR of the study population was $0.784+0.019$. The prevalence of overweight by WHR was $4.40 \%$ (19) with highest prevalence at 13 years of age $(9.80 \%)$ and lowest at 17 years of age $(2.10 \%)$. The prevalence of obesity by WHR was $3.30 \%$. Highest prevalence was seen at 12 years of age $(6.30 \%)$ and lowest prevalence of obesity by WHR was seen at 18 years of age $(1.70 \%)$.

On binary logistic regression analysis (multivariate analysis) a statistically significant relation was seen between the prevalence of overweight with age and SES. A higher prevalence of overweight was seen in 12-14 years age group $(\mathrm{p}=0.032)$ and the risk of being overweight was 2.682 times higher in 12-14 years age group than in 15-18 years age group.

A higher prevalence of overweight was seen in upper SE class than in middle class and lower class $(\mathrm{p}<0.001$ and $<0.001$ respectively). The risk of being overweight was about 14 times (1/0.071) higher in upper class than in middle class and 25.6 times (1/0.039) more in upper class than in lower class.

However, the association of the prevalence of thinness with residence, type of family, mother's literacy, mother's occupation and type of school was not found to be statistically significant (Table 6).

Table 8 shows the distribution of study population by their calorie intake (24 hours recall). 250 (58.4\%) of the adolescent girls were taking adequate calories, 134 $(31.3 \%)$ had a deficit calorie intake and 44 (10.30\%) were taking excess calories. ${ }^{12}$ 
Table 4: Relation between BMI of study population and their sociodemographic variables.

\begin{tabular}{|c|c|c|c|c|c|c|c|c|c|c|}
\hline \multirow{2}{*}{\multicolumn{2}{|c|}{ Sociodemographic variable }} & \multicolumn{2}{|c|}{ Total } & \multicolumn{2}{|c|}{$\begin{array}{l}\text { Normal (BMI } \\
-2 \text { SD to +1SD) }\end{array}$} & \multicolumn{2}{|c|}{$\begin{array}{l}\text { Thin } \\
\text { (BMI <-2SD) }\end{array}$} & \multicolumn{3}{|c|}{$\begin{array}{l}\text { Overweight (BMI } \\
>\text { 1SD) }\end{array}$} \\
\hline & & $\mathrm{N}$ & $\%$ & $\mathrm{n}$ & $\%$ & $\mathrm{n}$ & $\%$ & $\mathrm{n}$ & $\%$ & $\mathrm{p}$ value \\
\hline \multirow[t]{3}{*}{ Age } & $12-14$ years & 162 & 37.90 & 84 & 51.90 & 60 & 37.03 & 18 & 11.10 & \multirow[t]{2}{*}{0.035} \\
\hline & $15-18$ years & 266 & 62.10 & 160 & 60.20 & 93 & 34.96 & 13 & 4.90 & \\
\hline & & \multicolumn{2}{|c|}{$\begin{array}{l}\text { p value, } \\
\text { Odd's } \\
\text { Ratio(OR), } \\
95 \% \text { CI for } \\
\text { OR }\end{array}$} & \multicolumn{2}{|c|}{$\begin{array}{l}\text { Reference } \\
\text { category }\end{array}$} & \multicolumn{2}{|c|}{$\begin{array}{l}\mathrm{p}=0.334 \\
\mathrm{OR}=1.229 \\
(0.809-0.867)\end{array}$} & \multicolumn{2}{|c|}{$\begin{array}{l}\mathrm{p}=0.010 \\
\mathrm{OR}=2.637 \\
(1.233-5.643)\end{array}$} & \\
\hline \multirow{4}{*}{$\begin{array}{l}\text { Socioeconomic } \\
\text { status }\end{array}$} & Upper class & 72 & 16.82 & 37 & 51.40 & 12 & 16.66 & 23 & 31.90 & \multirow[t]{3}{*}{$<0.001$} \\
\hline & Middle class & 161 & 37.62 & 119 & 73.90 & 36 & 22.36 & 6 & 3.70 & \\
\hline & Lower class & 195 & 45.56 & 88 & 45.10 & 105 & 53.84 & 2 & 1.00 & \\
\hline & & \multicolumn{2}{|c|}{$\mathrm{p}$ value } & \multicolumn{2}{|c|}{$\begin{array}{l}\text { Reference } \\
\text { category }\end{array}$} & \multicolumn{2}{|c|}{$\mathrm{p}<0.001$} & \multicolumn{2}{|c|}{$\mathrm{P}<0.001$} & \\
\hline \multirow[t]{3}{*}{ Residence } & Rural & 207 & 48.40 & 113 & 54.60 & 85 & 41.06 & 9 & 4.30 & \multirow[t]{2}{*}{0.016} \\
\hline & Urban & 221 & 51.60 & 131 & 59.30 & 68 & 30.76 & 22 & 10.00 & \\
\hline & & \multicolumn{2}{|c|}{$\begin{array}{l}\text { p value, } \\
\text { Odd's } \\
\text { Ratio(OR), } \\
95 \% \text { CI for } \\
\text { OR }\end{array}$} & \multicolumn{2}{|c|}{$\begin{array}{l}\text { Reference } \\
\text { category }\end{array}$} & \multicolumn{2}{|c|}{$\begin{array}{l}\mathrm{p}=0.073 \\
\mathrm{OR}=1.449 \\
(0.965-2.175)\end{array}$} & \multicolumn{2}{|c|}{$\begin{array}{l}\mathrm{p}=0.001 \\
\mathrm{OR}=4.444 \\
(1.748-11.298)\end{array}$} & \\
\hline \multirow[t]{3}{*}{ Type of family } & Nuclear & 300 & 70.10 & 164 & 54.70 & 113 & 37.67 & 23 & 7.70 & \multirow[t]{2}{*}{0.325} \\
\hline & Joint & 128 & 29.90 & 80 & 62.50 & 40 & 31.25 & 8 & 6.20 & \\
\hline & & \multicolumn{2}{|c|}{$\begin{array}{l}\text { p value, } \\
\text { Odd's } \\
\text { Ratio(OR), } \\
95 \% \text { CI for } \\
\text { OR }\end{array}$} & \multicolumn{2}{|c|}{$\begin{array}{l}\text { Reference } \\
\text { category }\end{array}$} & \multicolumn{2}{|c|}{$\begin{array}{l}\mathrm{p}=0.161 \\
\mathrm{OR}=1.378 \\
(0.880-2.159)\end{array}$} & \multicolumn{2}{|c|}{$\begin{array}{l}\mathrm{p}=0.433 \\
\mathrm{OR}=1.402 \\
(0.601-3.274)\end{array}$} & \\
\hline \multirow[t]{3}{*}{ Mother's literacy } & Illiterate & 207 & 48.40 & 108 & 52.20 & 84 & 40.60 & 15 & 7.20 & 0.119 \\
\hline & Literate & 221 & 51.60 & 136 & 61.50 & 69 & 31.20 & 16 & 7.20 & \\
\hline & & \multicolumn{2}{|c|}{$\begin{array}{l}\text { p value, } \\
\text { Odd's } \\
\text { Ratio(OR), } \\
95 \% \text { CI for } \\
\text { OR }\end{array}$} & \multicolumn{2}{|c|}{$\begin{array}{l}\text { Reference } \\
\text { category }\end{array}$} & $\begin{array}{l}\mathrm{p}=0 \\
\mathrm{OR}= \\
(1.0\end{array}$ & $\begin{array}{l}33 \\
2.302)\end{array}$ & $\begin{array}{l}\mathrm{p}=0 \\
\mathrm{OR} \\
(0.5\end{array}$ & 195) & \\
\hline Mother's & Homemaker & 339 & 79.20 & 186 & 54.90 & 128 & 37.76 & 25 & 7.40 & 0.202 \\
\hline Occupation & Working & 89 & 20.80 & 58 & 65.20 & 25 & 28.09 & 6 & 6.7 & \\
\hline & & $\begin{array}{l}\mathrm{p} \mathrm{va} \\
\text { Odd } \\
\text { Rati } \\
95 \% \\
\text { OR }\end{array}$ & $\begin{array}{l}\text { e, } \\
\text { OR), } \\
\text { CI for }\end{array}$ & $\begin{array}{l}\text { Refe } \\
\text { cate }\end{array}$ & $\begin{array}{l}\text { ence } \\
\text { ry }\end{array}$ & $\begin{array}{l}\mathrm{p}<0 \\
\mathrm{OR}= \\
(0.1\end{array}$ & $\begin{array}{l}97 \\
.449)\end{array}$ & $\begin{array}{l}\mathrm{p}=0 \\
\mathrm{OR} \\
(0.2\end{array}$ & (98) & \\
\hline Type of school & Government & 242 & 56.50 & 134 & 55.40 & 91 & 37.60 & 17 & 7.00 & 0.659 \\
\hline & Private & 186 & 43.50 & 110 & 59.10 & 62 & 33.33 & 14 & 7.50 & \\
\hline & & $\begin{array}{l}\mathrm{p} \text { val } \\
\text { Odd } \\
\text { Rati } \\
95 \% \\
\text { OR }\end{array}$ & $\begin{array}{l}\text { e, } \\
\text { OR), } \\
\text { CI for }\end{array}$ & $\begin{array}{l}\text { Refe } \\
\text { cate }\end{array}$ & $\begin{array}{l}\text { ence } \\
\text { ry }\end{array}$ & $\begin{array}{l}p=0 \\
\text { OR= } \\
(0.8\end{array}$ & $\begin{array}{l}05 \\
.815)\end{array}$ & $\begin{array}{l}\mathrm{p}=0 \\
\mathrm{OR} \\
(0.4\end{array}$ & 7 12) & \\
\hline
\end{tabular}


Table 5: Binary logistic regression analysis (multivariate analysis) of various factors associated with thinness.

\begin{tabular}{|c|c|c|c|c|c|c|}
\hline & & \multirow[t]{2}{*}{ p value } & \multirow{2}{*}{$\begin{array}{l}\text { Odd's } \\
\text { ratio } \\
\text { (OR) }\end{array}$} & \multicolumn{2}{|c|}{$\begin{array}{l}95 \% \text { confidence } \\
\text { interval for OR }\end{array}$} & \multirow[t]{2}{*}{$\begin{array}{l}\text { Reference } \\
\text { category }\end{array}$} \\
\hline & & & & lower & upper & \\
\hline Age group & $12-14$ years & 0.316 & 1.263 & 0.800 & 1.993 & $15-18$ years \\
\hline \multirow[t]{2}{*}{ SES } & Middle Class & 0.900 & 0.951 & 0.437 & 2.072 & \multirow[t]{2}{*}{ Upper Class } \\
\hline & Lower Class & $<0.001$ & 3.690 & 1.774 & 7.675 & \\
\hline Residence & Rural & 0.587 & 1.152 & 0.691 & 1.919 & Urban \\
\hline Type of family & Nuclear & 0.201 & 1.365 & 0.847 & 2.200 & Joint \\
\hline Mother's literacy & Illiterate & 0.256 & 1.383 & 0.791 & 2.414 & Literate \\
\hline Mother's occupation & Working & 0.441 & 0.775 & 0.406 & 1.482 & Homemaker \\
\hline Type of school & government & 0.584 & 0.852 & 0.481 & 1.509 & Private \\
\hline
\end{tabular}

Table 6: Binary logistic regression analysis (multivariate analysis) of various factors associated with overweight.

\begin{tabular}{|c|c|c|c|c|c|c|}
\hline & & \multirow[t]{2}{*}{ p value } & \multirow{2}{*}{$\begin{array}{l}\text { Odd's } \\
\text { ratio } \\
\text { (OR) }\end{array}$} & \multicolumn{2}{|c|}{$\begin{array}{l}95 \% \text { confidence } \\
\text { interval for } \mathrm{OR}\end{array}$} & \multirow[t]{2}{*}{$\begin{array}{l}\text { Reference } \\
\text { category }\end{array}$} \\
\hline & & & & lower & upper & \\
\hline Age group & $12-14$ years & 0.032 & 2.682 & 1.089 & 6.605 & $15-18$ years \\
\hline \multirow[t]{2}{*}{ SES } & Middle Class & $<0.001$ & 0.071 & 0.024 & 0.207 & \multirow[t]{2}{*}{ Upper Class } \\
\hline & Lower Class & $<0.001$ & 0.039 & 0.008 & 0.181 & \\
\hline Residence & Rural & 0.433 & 0.671 & 0.248 & 1.817 & Urban \\
\hline Type of family & Nuclear & 0.340 & 1.618 & 0.602 & 4.350 & Joint \\
\hline Mother's literacy & Illiterate & 0.608 & 0.729 & 0.218 & 2.434 & Literate \\
\hline Mother's occupation & Working & 0.813 & 0.862 & 0.252 & 2.951 & Homemaker \\
\hline Type of school & government & 0.929 & 0.950 & 0.306 & 2.952 & Private \\
\hline
\end{tabular}

Table 7: Age wise distribution of the study population by their mean WHR.

\begin{tabular}{|c|c|c|c|c|c|c|c|c|c|}
\hline \multirow[t]{2}{*}{ Age } & \multicolumn{2}{|c|}{ Total } & \multirow{2}{*}{$\begin{array}{l}\text { WHR } \\
\text { Mean } \pm \text { SD }\end{array}$} & \multicolumn{2}{|c|}{$\begin{array}{l}\text { Normal } \\
(\text { WHR }<0.80)\end{array}$} & \multicolumn{2}{|c|}{$\begin{array}{l}\text { Overweight (WHR } \\
\text { 0.80-0.84) }\end{array}$} & \multicolumn{2}{|c|}{$\begin{array}{l}\text { Obese } \\
(\mathrm{WHR} \geq 0.85)\end{array}$} \\
\hline & $\mathbf{n}$ & $\%$ & & $\mathbf{n}$ & $\%$ & n & $\%$ & $\mathbf{n}$ & $\%$ \\
\hline 12 & 63 & 14.71 & $0.789 \pm 0.027$ & 54 & 85.70 & 5 & 7.90 & 4 & 6.30 \\
\hline 13 & 51 & 11.91 & $0.788 \pm 0.024$ & 43 & 84.30 & 5 & 9.80 & 3 & 5.90 \\
\hline 14 & 48 & 11.21 & $0.784 \pm 0.018$ & 46 & 95.80 & 0 & 0.00 & 2 & 4.20 \\
\hline 15 & 42 & 9.81 & $0.785 \pm 0.023$ & 37 & 88.10 & 3 & 7.10 & 2 & 4.80 \\
\hline 16 & 68 & 15.88 & $0.780 \pm 0.012$ & 64 & 94.10 & 4 & 5.90 & 0 & 0.0 \\
\hline 17 & 97 & 22.66 & $0.782 \pm 0.017$ & 93 & 95.90 & 2 & 2.10 & 2 & 2.10 \\
\hline 18 & 59 & 13.78 & $0.781 \pm 0.012$ & 58 & 98.30 & 0 & 0.00 & 1 & 1.70 \\
\hline Total & 428 & 100.00 & $0.784 \pm 0.019$ & 395 & 92.30 & 19 & 4.40 & 14 & 3.30 \\
\hline
\end{tabular}

Table 8: Distribution of the study population by their calorie intake ( 24 hour recall).

\begin{tabular}{|lll|}
\hline Calorie intake & $\mathbf{n}$ & \% \\
\hline < RDA (deficit) & 134 & 31.30 \\
\hline Adequate & 250 & 58.40 \\
\hline >RDA (Excess) & 44 & 10.30 \\
\hline Total & 428 & 100.00 \\
\hline
\end{tabular}

Table 9 depicts the relation between BMI and calorie intake. It was observed that BMI of the study population was significantly associated with their calorie intake $(\mathrm{p}<$ $0.001)$. It was seen that the prevalence of thinness was highest in those taking deficit calories $(44.80 \%)$ and the association was statistically significant $(p=0.005)$. The prevalence of overweight was highest in adolescents 
taking excess calories $(25.00 \%)$ and the association was statistically significant $(\mathrm{p}<0.001)$.

Table 10 depicts the distribution of study population by the level of physical activity. 141 (32.9\%) of the study population did not engage in any physical activity, 245 $(57.2 \%)$ of the study population was physically active on 5 days or less every week and $42(9.8 \%)$ were physically active on more than 5 days a week.

Table 11 depicts the relation of BMI with level of physical activity of the study population. Overall there was no significant association between BMI and physical activity of the study population $(\mathrm{p}=0.735)$.

Table 12 shows the distribution of the study population on the basis of the frequency of junk food consumption.
It was observed that $372(86.90 \%)$ study girls consumed junk foods almost every day, $51(11.90 \%)$ consumed junk foods either less than or once a week and only 5 (1.20\%) consumed junk food occasionally.

Table 13 shows the relation between BMI of the study population and junk food consumption. Among overweight girls, $87.1 \%$ took junk food every day, while $9.7 \%$ took junk food < once a week and $3.20 \%$ took it occasionally. Among thin also there was a higher prevalence of junk food intake almost every day $(86.30 \%)$ followed by < once a week in $13.07 \%$ girls and $0.70 \%$ who took junk food occasionally. The association between junk food intake and BMI was not found to be statistically significant $(\mathrm{p}=0.663)$.

Table 9: Relation between BMI and calorie intake of the study population.

\begin{tabular}{|c|c|c|c|c|c|c|c|c|c|}
\hline \multirow[t]{2}{*}{$\begin{array}{l}\text { Calorie } \\
\text { intake } \downarrow\end{array}$} & \multicolumn{2}{|c|}{ Total } & \multicolumn{2}{|c|}{$\begin{array}{l}\text { Normal (BMI } \\
-2 S D \text { to +1SD) }\end{array}$} & \multicolumn{2}{|c|}{$\begin{array}{l}\text { Thin } \\
\text { (BMI <-2SD) }\end{array}$} & \multicolumn{2}{|c|}{ Overweight (BMI > 1SD) } & \multirow[t]{2}{*}{ p value } \\
\hline & $\mathrm{n}$ & $\%$ & $\mathrm{n}$ & $\%$ & $\mathrm{n}$ & $\%$ & $\mathrm{n}$ & $\%$ & \\
\hline Adequate & 250 & 31.30 & 163 & 65.20 & 77 & 30.80 & 10 & 4.00 & \multirow[t]{3}{*}{$<0.001$} \\
\hline$>$ RDA (excess) & 44 & 58.40 & 17 & 38.60 & 16 & 36.40 & 11 & 25.00 & \\
\hline$<$ RDA (deficit) & 134 & 10.30 & 64 & 47.80 & 60 & 44.80 & 10 & 7.50 & \\
\hline & \multicolumn{2}{|c|}{ p value } & \multicolumn{2}{|c|}{$\begin{array}{l}\text { Reference } \\
\text { category }\end{array}$} & \multicolumn{2}{|c|}{$p=0.005$} & \multicolumn{2}{|c|}{$p<0.001$} & \\
\hline Total & 428 & 100.00 & 244 & 57.00 & 153 & 35.70 & 31 & 7.20 & \\
\hline
\end{tabular}

Table 10: Distribution of the study population by the level of physical activity.

\begin{tabular}{|lll|}
\hline Frequency & $\mathbf{n}$ & \% \\
\hline Never & 141 & 32.90 \\
\hline$<5$ days a week & 245 & 57.20 \\
\hline$>5$ days a week & 42 & 9.80 \\
\hline Total & 428 & 100.00 \\
\hline
\end{tabular}

Table 11: Relation between BMI of the study population and physical activity.

\begin{tabular}{|c|c|c|c|c|c|c|c|c|c|}
\hline & \multicolumn{2}{|c|}{ Total } & \multicolumn{2}{|c|}{$\begin{array}{l}\text { Normal (BMI } \\
-2 S D \text { to +1SD) }\end{array}$} & \multicolumn{2}{|c|}{$\begin{array}{l}\text { Thin } \\
\text { (BMI <-2SD) }\end{array}$} & \multicolumn{2}{|c|}{$\begin{array}{l}\text { Overweight (BMI } \\
>\text { 1SD) }\end{array}$} & \multirow[t]{2}{*}{ p value } \\
\hline $\begin{array}{l}\text { physical } \\
\text { activity } \downarrow\end{array}$ & $\mathrm{N}$ & $\%$ & $\mathrm{n}$ & $\%$ & $\mathrm{n}$ & $\%$ & $\mathrm{n}$ & $\%$ & \\
\hline Never & 141 & 32.90 & 80 & 56.70 & 50 & 35.50 & 11 & 7.80 & \multirow[t]{3}{*}{$\mathrm{P}=0.735$} \\
\hline $\begin{array}{l}<5 \text { days a } \\
\text { week }\end{array}$ & 245 & 57.20 & 141 & 57.60 & 85 & 34.70 & 19 & 7.80 & \\
\hline \multirow{2}{*}{$\begin{array}{l}>5 \text { days a } \\
\text { week }\end{array}$} & 42 & 9.80 & 23 & 54.80 & 18 & 42.90 & 1 & 2.40 & \\
\hline & \multicolumn{2}{|c|}{$\mathrm{p}$ value } & \multicolumn{2}{|c|}{$\begin{array}{l}\text { Reference } \\
\text { category }\end{array}$} & \multicolumn{2}{|c|}{$\mathrm{p}=0.748$} & \multicolumn{2}{|c|}{$\mathrm{p}=0.647$} & \\
\hline Total & 428 & 100.00 & 244 & 57.00 & 153 & 35.70 & 31 & 7.20 & \\
\hline
\end{tabular}


Table 12: Distribution of the study population by frequency of junk food consumption.

\begin{tabular}{|lll|}
\hline Frequency & $\mathbf{N}$ & $\%$ \\
\hline Occasionally & 5 & 1.20 \\
\hline Sonce a week & 51 & 11.90 \\
\hline Almost everyday & 372 & 86.90 \\
\hline Total & 428 & 100.00 \\
\hline
\end{tabular}

Table 13: Relation between BMI of the study population consumption and frequency of junk food.

\begin{tabular}{|c|c|c|c|c|c|c|c|c|c|}
\hline \multirow[t]{2}{*}{$\mathbf{B M I} \downarrow$} & \multicolumn{2}{|c|}{ Total } & \multicolumn{2}{|c|}{$\begin{array}{l}\text { Junk food } \\
\text { consumption } \\
\text { occasionally }\end{array}$} & \multicolumn{2}{|c|}{$\begin{array}{l}\text { Junk food } \\
\text { consumption } \\
\text { sonce a week }\end{array}$} & \multicolumn{2}{|c|}{$\begin{array}{l}\text { Junk food } \\
\text { consumption } \\
\text { Almost everyday }\end{array}$} & \multirow[t]{2}{*}{ p value } \\
\hline & $\mathrm{n}$ & $\%$ & $\mathrm{n}$ & $\%$ & $\mathrm{n}$ & $\%$ & $\mathrm{n}$ & $\%$ & \\
\hline $\begin{array}{l}\text { Normal (BMI } \\
-2 S D \text { to }+1 S D)\end{array}$ & 244 & 57.00 & 3 & 1.20 & 28 & 11.50 & 213 & 87.30 & \multirow[t]{4}{*}{0.663} \\
\hline THIN (BMI <-2SD) & 153 & 35.70 & 1 & 0.70 & 20 & 13.07 & 132 & 86.30 & \\
\hline $\begin{array}{l}\text { Overweight (BMI } \\
\text { >1SD) }\end{array}$ & 31 & 7.20 & 1 & 3.20 & 3 & 9.70 & 27 & 87.10 & \\
\hline Total & 428 & 100.00 & 5 & 1.20 & 51 & 11.90 & 372 & 86.90 & \\
\hline
\end{tabular}

\section{DISCUSSION}

The present study revealed that overall prevalence of thinness in the study population was $35.70 \%$. Anand K et al observed almost a similar prevalence (30.1\%) of thinness in north Indian rural school going girls near Delhi. ${ }^{5}$ A higher prevalence of thinness among adolescent girls was observed by Wasnik V et al in Andhra Pradesh $(56.4 \%)$ and a much lower prevalence was seen by Vashisht B M et al (15.1\%) in Haryana. ${ }^{13,14}$

The prevalence of thinness was significantly associated with SES, mothers literacy and mothers occupation ( $\mathrm{p}$ value $<0.001,0.039$ and $<0.001$ respectively). It was observed that prevalence of thinness was higher in lower SE class $(53.84 \%)$ followed by middle class $(22.36 \%)$ and upper class $(16.66 \%)$. The higher prevalence of thinness in lower SE classes may be because of lesser dietary intake due to economic constraints than those from higher SE classes. Similar findings were reported by Maiti $\mathrm{S}$ et al in West Bengal where the prevalence of thinness $(27.09 \%)$ was highest in Socio-economic class IV. ${ }^{15}$ However Das DK et al in their study on adolescent girls in West Bengal did not find any association between socioeconomic status and prevalence of thinness. ${ }^{16}$

It was observed in our study that the prevalence of thinness was significantly higher in participants with illiterate mothers $(40.60 \%, \mathrm{p}=0.039)$ and whose mothers were homemakers by occupation (37.76\%,p value $<0.001)$. This again can be explained by the fact that illiterate mothers are less aware of the nutritional needs of their children and thus resulting in their inappropriate feeding leading to under nutrition. In a study conducted by Bhattacharyya $\mathrm{H}$ et al in Assam the prevalence of thinness $(44.26 \%)$ was significantly higher among girls who came from families whose mother's were illiterate which is in concordance with the present study. ${ }^{18}$ Contrary to this, Das D K et al in their study in West Bengal reported a significantly higher prevalence of thinness in adolescents whose mothers were literate. ${ }^{16}$

The prevalence of over-weight in the present study was $7.20 \%$. However an encouraging finding was that none of the study participants was obese as per BMI for age. Omobuwa $\mathrm{O}$ et al in their study on in- school adolescents in Nigeria found that $7.6 \%$ of them were overweight or obese which was similar to the results of our study. ${ }^{18}$ Mehta M et al and Sood A et al (Bangalore) in their study reported a prevalence of overweight $15.2 \%$ and $13.1 \%$, respectively, which was much higher than our study. ${ }^{19,20}$

It was observed that age, SES and residence had a significant association with the prevalence of overweight ( $\mathrm{p}$ value $0.010,<0.001$ and 0.001 ). Prevalence of overweight was more in 12-14 years age group (11.10\%), adolescents belonging to upper SE class (31.90\%) and adolescents from urban background (10.00\%). A higher prevalence of overweight in upper class may be because adolescents from upper SE classes have a better dietary intake than those from lower SE classes. Also adolescents from urban background might be having better dietary intake and have easier access to junk food than those from rural areas making them more prone to overweight and obesity. Similar to our study overweight was marginally higher in the pubertal age group, i.e., 13 to 15 years of age in studies done in Delhi and Chennai. ${ }^{21}$

However highest prevalence of overweight was seen in 14 years $(22.72 \%)$ and 13years $(20.83 \%)$ in a study conducted by Kowsalya $\mathrm{T}$ et al in Salem, India. ${ }^{22}$ 
Luxmaiah A et al reported that overweight in adolescents in Hyderabad was significantly higher $\left(p_{-} 0.05\right)$ among the adolescents of high SES (15\%) compared with those of low SES (3.3\%) and this was in concordance with the present study. ${ }^{23}$

A study conducted by Sachan B et al also observed that in urban girls of Lucknow the prevalence of overweight was more $(5.4 \%)$ than in rural girls $(3.9 \%){ }^{24}$ These findings were in concordance with our study. However, contrary to this Kowasalya $\mathrm{T}$ et al reported that the prevalence rate of overweight/obesity was higher in rural $(13.16 \%)$ than urban $(11.33 \%)$ area in adolescents (Salem, India). ${ }^{22}$

The mean WHR of the study population was $0.784+0.019$. The prevalence of overweight by WHR was $4.40 \%$ and that of obesity by WHR was $3.30 \%$. In the present study a total of $33(7.71 \%)$ adolescents had a waist hip ratio of $>0.80$ while as in a study conducted by Kumar C M et al in Andhra Pradesh 35\% adolescent girls had a waist hip ratio of $>0.80$ which is much higher than the present study. ${ }^{25}$ A higher prevalence was also reported by Kaur $S$ et al in nursing students in Chandigarh aged 17-23 years where the percentage of overweight and obesity was 23.28 and 7.84 respectively based on waist hip ratio. ${ }^{10}$

In the present study there was no significant association between BMI and physical activity of the study population. However it was seen by Luxmaiah A et al that the prevalence of overweight and obesity $(3.1 \%)$ was significantly lower among the adolescents in Hyderabad who participated in outdoor games ( $p$ value 0.004 ) than among the non-participants $(9.7 \%){ }^{23}$

In the present study it was observed that $86.90 \%$ adolescent girls consumed junk foods almost every day. This is in concordance with a study conducted by Kaur S et al in Chandigarh who found that most of the study participants $(94.18 \%)$ were in the habit of consuming junk and fried foods. ${ }^{10}$

In the present study the association between junk food intake and BMI of the adolescent girls was not found to be statistically significant $(\mathrm{p}=0.663)$. However Jain $\mathrm{G}$ et al found that the magnitude of overweight $(23.8 \%)$ and obesity $(8.4 \%)$ was very high and alarming and eating habits like junk food had a remarkable effect on prevalence on overweight and obesity among adolescents in Chhattisgarh. ${ }^{26}$

\section{CONCLUSION}

Thus it is concluded from this study that a considerable proportion of adolescent girls were thin, overweight and obese.

In this regard, parents as well as teachers should be sensitized on these issues and the role of healthy diet in preventing these problems should be emphasized. Since obesity is a risk factor for various non-communicable diseases like hypertension and diabetes, these adolescents need to be educated about the importance of a healthy diet and physical activity and about the consequences of junk food consumption which can be successfully done by teachers. Policymakers should be informed about the needs of young people and advocate for need based policy and program changes.

\section{Funding: No funding sources \\ Conflict of interest: None declared \\ Ethical approval: Not required}

\section{REFERENCES}

1. Ghai OP. Textbook of essential paediatrics. $6^{\text {th }} \mathrm{ed}$. New Delhi: CBS Publishers; 2005:66-67,73,76,78.

2. Kansal OP, Ohri P. Adolescents: a key pivotal in India's health strategy. IJoYAH. 2014;1(2):48-55.

3. Lal S, Pankaj A. Textbook of Community Medicine. $3^{\text {rd }}$ ed. New Delhi: CBS Publishers; 2013:155-6.

4. WHO Nutrition in adolescents-Issues and challenges for the health sector. 2005:1.

5. Anand K, Kant S, Kapoor SK. Nutritional status of adolescent school children in rural north India. Indian J paediatr.1999;36:810-16.

6. Kapil U, Singh P, Pathak P, Bhasin S. Prevalence of obesity amongst affluent adolescent school children in Delhi. Indian J paediatr. 2002;39(5):449-52.

7. www.dsek.nic.in. Accessed on $12^{\text {th }}$ March 2015.

8. International Institute for Population Sciences (IIPS), 2010. District Level Household and Facility Survey (DLHS-3 India). 2007-08:41. Accessed on $20^{\text {th }}$ Feb, 2015.

9. www.who.int. 2014. Available at: http://www.who.int/growth_ref/who2007_bmi_for_ age/en/. Accessed on $10^{\text {th }}$ Oct, 2014.

10. Kaur S, Walia I. Body mass index, waist circumference and waist hip ratio among nursing students. Nursing and Midwifery Research Journal. 2007;3(2):84-90.

11. Mangal A, Kumar V, Panesar S, Talwar R, Raut D, Singh S. Updated BG Prasad socioeconomic classification, 2014. A commentary. Indian J Public Health. 2015;59(1):42-4.

12. ICMR, nutrient requirement and recommended dietary allowances for Indians. A report of the expert group of the ICMR. 2010.

13. Wasnik V, Rao BS, Rao D. A study of health status of early adolescent girls residing in social welfare hostels in Vizianagaram district of AP, India. IJCRIMPH. 2012;4(1):72-83.

14. Vashist BM, Joyti, Goel MK. Nutritional status of adolescents in rural and urban Rohtak, Haryana. Health Popul Perspect Issues. 2009;32(4):190-7.

15. Maiti S, De D, Chatterjee K, Jana K, Ghosh D , Paul S. Prevalence of stunting and thinness among early adolescent school girls of Paschim Medinipur 
district, West Bengal. Int J Biol Med Res. 2011; 2(3):781-3.

16. Kumar DD, Biswas R. Nutritional status of adolescent girls in a rural area of North 24 Parganas District, West Bengal. Indian J Public Health. 2005; 49(1):18-21.

17. Bhattacharyya H, Barua A. Nutritional status and factors affecting nutrition among adolescent girls in urban slums of Dibrugarh, Assam. NJCM. 2013;4(1):35-9.

18. Omobuwa O, Alebiosu CO, Olajide FO, Adebimpe WO. Assessment of nutritional status of in school adolescents in Ibadan, Nigeria. SAFP. 2014;56(4):246-50.

19. Mehta M, Bhasin SK, Agrawal K, Dwivedi S. Obesity amongst affluent adolescent girls. Indian J Pediatr. 2007;74:619-22.

20. Sood A, Sundararaj P, Sharma S, Kurpad AV, Muthayya S. BMI and body fat percent: affluent adolescent girls in Bangalore city. Indian Pediatr. 2007;44:587-91.

21. Kaur S, Kapil U, Singh P. Pattern of chronic diseases amongst adolescent obese children in developing countries. Curr Sci. 2005;88:1052-6.
22. Kowsalya T, Parimalavalli R. Prevalence of overweight/obesity among adolescents in urban and rural areas of Salem. JOMR. 2014;1(3):152-5.

23. Laxmaiah A, Nagalla B, Vijayaraghavan K, Nair M. Factors affecting prevalence of overweight among 12 to 17 year-old urban adolescents in Hyderabad, India. Obesity. 2007;15(6):1384-90.

24. Sachan B, Idris MZ, Jain S, Kumari R, Singh A. Nutritional status of school going adolescent girls in Lucknow district. J Med Nutr Nutraceut. 2012; 1(2):101-5.

25. Kumar CM, Babu CS. Reproductive health problems of adolescent girls between 15 and 19 in Andhra Pradesh. Pak Peds J. 2012;36(4):225-34.

26. Jain G, Bharadwaj SK, Joglekar AR. To study the prevalence of overweight and obesity among school children (13-17 years) in relation to their socioeconomic status and eating habits. IJSRP. 2012;2(6).

Cite this article as: Darakshan A, Shah RJ, Fazili AB, Rafiq MM, Mushtaq B, Iqbal QM, Dar SY. A study on the prevalence of thinness and obesity in school going adolescent girls of Kashmir Valley. Int J Community Med Public Health 2016;3:1884-93. 